\title{
Coverage of crime and violence in Nigerian media: matters arising
}

\author{
E.O. Soola
}

Associate Professor

Department of Communication and Language arts

University of Ibadan

\begin{abstract}
Nigerias socio-political and economic landscape has been blighted by the endemic twin evil of crime and violence. Social responsibility media, framing, and attribution theories provide the theoretical anchor for this paper. Nigerian consumers of media products, like their counterparts in other cultures, are insatiably interested in, and are at times shocked and fascinated by, crime and violence, as covered in the media. The Nigerian mass media, acting both as mirrors of society and business enterprises, provide a daily diet of these crimes, howbeit deficiently. This deficiency is traceable to their episodic rather than thematic approach, their individual, instead of societal blame, and cause, rather than solution. Nigerian media, in many instances, fail to turn their searchlight on the undercurrents of crime and violence: the Nigerian system of justice and the issues and grievances that give rise to crime and violence in the society. The paper, as matters arising, critically examines the often ignored, and at best-perfunctorily handled, aspects of coverage of crime and violence in Nigerian media.
\end{abstract}

Nigeria's socio-political and economic landscape has been blighted by the endemic twin evil of crime and violence of major, tragic and alarming proportions. The widespread frustration and deep sense of insecurity to life and property, occasioned by this epidemic, has become a matter of grave concern to government, security agencies and the Nigerian citizenry at large (Nwosu, 2003). The situation has become most critical, consequent upon the apparent helplessness of the law-enforcement agencies to stem the tide of the epidemic (Otudor, 2005, Adebayo, 2006, Adeyemi, 2006, Adeyemi, 2007, Iziguzo, 2007)

The state of insecurity in Nigeria today is such that it is not an overstatement to conclude that the Nigerian nation is under siege. And while the urban centres are more prone to crimes, neither the urban, the sub-urban nor the rural is immune to civil, ethnic, political and religious violence which, in the last decade or so, have plagued Nigeria and currently threaten to tear communities and ethnic groups apart.

The current spate of crime and violence in Nigeria dates back to the end of the Nigerian civil war in 1970 when arms began to filter through into unauthorised hands. The situation was exacerbated by prolonged military interregnum, its brute force and the violence that characterised it. The sacredness with which human life used to be held until the early 1970s, was soon thrown to the winds by miscreants and other criminals. The situation was further compounded by Nigerian media's romance with foreign films which were generously laced with crime, violence and sex. The Nigerian home video, currently in vogue, is not better in that it thrives on similar themes - crimes, violence and sex.

Apart from the widespread availability of untracked arms, as well as crime and violence in the media, other possible causes of crime and violence include non-compulsory Universal Basic Education (UBE is made compulsory only on paper because of lack of political will and commitment to free education), widespread poverty (with Nigeria ranking 13th last 
poorest of the poor nations on earth), lack of social security for the aged and the unemployed, child abuse, incidents of violence in neighbourhoods and communities, (Azuatalam, O'neil \& Okafor,2007, Adeyemi, 2007, Azuatalam, 2007) disintegration of the nuclear and kinship family networks, gender insensitivity, availability of drugs and unprecedented widespread availability of alcohol which either comes raw as locally-brewed gin, popularly referred to in the local language as "ogogoro", or disguised in herbs, and fondly called "sungbalaja", or "opa eyin", literally translated as "lie flat, face-up" and "for the spinal cord" respectively, offered cure for all ailments under the sun! Drivers, touts, miscreants, political thugs and armed robbers buy such drugs and alcohol and take them even when they do not have either money or time to eat food!

\section{THEORETICAL FRAMEWORK}

\section{Social Responsibility Media Theory}

The notion that the media have a responsibility for contextualised, meaningful reporting dates back to the 1947 Hutchins Commission on the Freedom of the Press (Folarin, 1998, Coleman, 1999, Severin and Tankard Jr. 2001). The chief duty of the media operating within the context of this theory is to raise conflict to the plane of discussion. With specific reference to reporting crime and violence, Coleman (1999) has reasoned that, by providing information in a public health context, the media help to alter the basic conditions that predispose a society to, and sustain, crime and violence. Similarly, by reporting on underlying causes and societal factors, the media serve to facilitate discussion of crime and violence and its solutions, while encouraging the inclusion of views outside the dominant ideology, which perceive crime and violence as being individually-located, and its solution in terms of punishment rather than prevention.

\section{Framing Theory}

This theory, Coleman (1999: 5) has observed, was first introduced by sociologist Erving Goffman in the 19 70s to "systematically explain that humans use their ingrained expectations to make sense of their lives". He cites Severin \& Tankard as stating that events are framed or given a field of meanings within which they can be understood. Thus, frames focus attention on some issues or things, while blocking out or obscuring others. Severin \& Tankard, Jr. (2001: 287) quote Severin et al's definition of frame as "a central organizing idea for news content that supplies a context and suggests what the issue is through the use of selection, emphasis, exclusion and elaboration". Application of framing theory implies that a contextualised reporting of crime and violence takes audience's understanding and perception of crime and violence beyond the individual to the level of society. Applied to average of crime and violence, framing theory, work likely, will guarantee a contextualized reporting that not only takes due cognizance of audience's perception of this evil into consideration, but also situates crime and violence resulting within the broader spectrum of society.

\section{Attribution Theory}

An important concept in framing theory, attribution, according to Coleman (1999: 5), suggests that "people typically exaggerate the role of individual motives and intentions while discounting societal factors". This tendency to blame individuals has, according to Coleman, been dubbed by psychologists as the fundamental attribution error. Its link with framing 
theory arises from the fact that certain kinds of news frames tend to encourage attribution of responsibility to individuals, while other kinds of news frames tend to suggest that people will be more likely to hold society responsible. The choice in news coverage convention is between episodic frames and thematic frames. According to Coleman, while episodic news frames focus on specific events or particular cases, thematic news frames place issues in a general context. Episodic framing of crime and violence thus focuses on specific episodes, individual perpetrators, victims, or other actors at the expense of the more general, thematic information. The media's focus on episodic framing reinforces the dominant ideology of individual responsibility for crime and violence. By giving only episodic information in crime and violence reporting, the media are indirectly suggesting that there is nothing citizens or the community can do about the situation; thus serving to create a state of societal fearfulness and helplessness.

\section{Consequences of Crime and Violence in a Society}

Crime and violence have taken a severe toll on Nigeria, her people, its economy, its political, its social, and even its spiritual life. Crime and violence are so palpable, so pervasive and so devastating that many Nigerians now sleep with one eye opened when they do sleep at all (Nwosu, 2003, Azuatalam, 2007, Otudor, 2005). Even sacred places such as mosques and churches, and even cemeteries are not spared. With specific reference to crime, Nwosu (2001: 45) has observed that:

The threat to our lives and properties posed by crime is so palpable and real that we have become so paranoid that we now sleep with one eye open(sic)... That is, even after many of us have so barricaded our compounds, houses and rooms as if we are in prison yards. Yet we do not feel safe at all.

In Nigeria, today, many buildings are heavily fortified with walls cum steel fences which, in some cases, are higher than the houses they enclose, or even higher than prison walls. Traveling by road in the day time, but particularly by night, has become increasingly hazardous, as passengers may be violently dispossessed of their personal effects and are at times massacred in the process.

Stevens (1998: 16) has painted a gloomy picture of the dire consequences of crime and violence. In her words:

Each incident reverberates through the families of perpetrator and victim, with long-term economic consequences (loss of job, loss of home, loss of income, medical bills, attorney bills) and psychological consequences (sense of loss, fear, alienation, trial, welfare, reduction in property values, business flight and long-term psychological consequences (feelings of fear for personal safety, mistrust of members of community).

So, when crime and violence afflict our society, they leave a tale of woe and anguish in their wake. They are an ill-wind which blows nobody any good, as both perpetrator and victim suffer severe consequences. Little wonder that Nigeria has become a pariah state, treated as if it were, a leprous nation, shunned by tourists and investors whose personal security and the security of their investment Nigeria cannot guarantee.

\section{Media, Crime and Violence}


Media operators, and by extension the media especially television, by reason of its visual appeal, and generate revenue from coverage of savour and feed on crime and violence. As Dorfman \& Thorson (1998) have observed, "reporting on crime and violence has been a staple in newspaper diet since before the penny press". Crime and violence make and sell headlines and news programmes. Crime and violence make news reports juicy; they are sensational, dramatic and sometimes, colourful. Since media owners are in business to make profit, and since crime and violence sell newspapers and programmes, causing circulation figures and programme ratings to soar, no media operators are likely to spew out a juicy rape, commando-like bank robbery, murder, high-profile assassination or a monumental fraud. To that extent, crime and violence are not only attractive, but they are also tempting to media operators.

\section{According to Dorfman and Thorson (1998: 5):}

Although some people might get information about violence from personal experience as victims or mistresses, most do not experience crime and violence personally. Instead much of their information or perceptions about crime come from the news.

Crime and violence enjoy lavish space and time for some other reason: they are ridiculously easy to cover (Sandman, Rubin, \& Sachsman, 1976) An unadventurous reporter may choose to sit at a police desk, monitor police radio, or liaise with a court clerk or registrar, while occasionally telephoning smaller police stations and courts in the community to check for new developments. At the approach of the deadline, the reporter calls the newsroom to dictate any newsworthy occurrence for the day.

This approach to the coverage of crime and violence is deficient in many ways. Here, because the reporter works hand-in-gloves with the police and the court, crime reporting, according to Sandman, Rubin and Sachsman (1976: 412), almost invariably favours the official viewpoint. Since the reporter is unlikely to meet face-to-face with the accused, the suspect's protestations of innocence or accusation of police brutality often go unreported. The reporter is also denied the knowledge of underlying causes of crime or the motives for a particular crime. He is also most likely to fail to critically examine the fact that many criminal acts today are a reflection of social unrest of political repression, of joblessness, and systematic exclusion from 'the good life'. Example include endemic cases of kidnapping and hostagetaking by restive youths in Nigeria's oil-rich Niger Delta region (Olaniyi, 2006, Daniel, 2006, Adebayo, 206, Azuatalam, O'neil, 2007), political assassination (Adeyemi, 2007, Rasaq 2006), rampant incidence of armed robbery (Obe, 2006, Adeyemi, 2007, Otudor, 2005), led at times by unemployed youths, some of whom are university graduates. Such factors are far seldom adequately covered by the media.

A decontextualised coverage of crime and violence usually blurs the audience's understanding of the crime situation. As Hawkey "http://tinyur/.com/8zctp / Friday 22 July 2005 has noted, concerning British media coverage of the July 17, 2005 London bombings:

We want to understand the bombing, can't afford not to do so. Media coverage of the attacks, that has clipsed all other news for days should make it easier for us to understand... Now our media are full of indignant denial. This doesn't help us understand the events and their causes. With few exceptions, such as some commentary from the Guardian and Channel 4, the mainstream media seem to be missing some important questions. 
The focus on the bizarre, the dramatic, as well as dependence on police and/or court sources often leads to disproportionate emphasis being placed on arrests rather than on trials (Sandman, Rubin \& Sachsman, 1972, Steven, 1998). News of arrests and convictions are dramatic and one-off. News of trials, on the other hand, is more demanding on the reporter and is only of interest to the audience if the trial is juicy and of critical, practical and immediate significance to them. Thus, a suspect's acquittal or dropped charges are hardly newsy and often go unreported.

The use of police or court officials is also faulted for yet another reason: it often leads to decontextualised reporting, one in which the reporter denies the audience the necessary background to put the story in context. The reporter is likely to fail to ask: was it (the crime) the act of an isolated offender or was it part of an organised effort citizens should be aware of? If it was the former, what brought the perpetrators to the point? Are there social or community pressures in play? How many such incidences have there been, and to what effect?

\section{Why Crime and Violence Stories are Attractive to the Audience}

It is intriguing to note that crime and violence stories are attractive not only to media operators and the media, but also to consumers of media products, though for different reasons. Media audiences' craze for crime and violence is rooted less in excitement than in fear. The fear of crime, according to Sandman, Rubin and Sachsman (1976: 412), is "'stark, widespread and very, very real". So, by covering crime and violence, the media are, in media parlance, "giving the audience what the audience wants". As www.presscouncil.or.an (2000) has argued, "people are entitled to know their enemies and full descriptions of assailants should be given so that one can be on one's guard". Although the same author has reasoned that "details of attacks... have alerted hoodlums in our society to the vulnerability of such defenseless people who are seen as easy game", the elderly will, nonetheless, "concede that media reports have put them on guard to expect attacks".

Similarly, The West Australian (www.presscouncil.org.au , has observed that:

It would be failing in its obligations to the readers if it did not report crimes and reflect community anxieties about them. At one level, such reports send unequivocal messages to people to take measures to protect themselves and their properties.

With specific relevance to violence, Sandman, Rubin \& Sachsman (1976: 417) have reasoned that:

People need to know if the streets are blocked or dangerous, some of those planning to drive or walk through the area of a disturbance may choose another route if they are told what is happening.

They warned:

A news blackout sets a dangerous precedent. Word-of-mouth rumors are likely to be even less accurate than the mass media. And if serious grievance has festered to the point of a riot, the public has a right to know.

\section{HOW CRIME AND VIOLENCE ARE COVERED IN NIGERIAN MEDIA}




\section{Drugs/Medicament}

In Nigeria, two types of drug-related reportage are a common feature of the press (Udoh, 2005, Udoma, 2006). This first type of coverage focuses on the manufacture or importation of adulterated, fake or substandard drugs whose use or intake is considered injurious to health. This phenomenon had, for years, threatened to undermine government's efforts, aimed at qualitative health delivery to the generality of the population (Okoli, 2007, Ogundipe, 2007). To regulate the manufacture and importation of drugs, the Nigerian government had established the National Agency for Food, Drug Administration and Control (NAFDAC) with virtually all the newspapers and magazines carrying screaming banner headlines (Ughegbe, Olatunji \& Dike, 2004, Olatunji, 2005, Oladipo, 2006, Owuamanam, 2006), while government and private radio and TV stations report them as major news items which has waged a relentless war on unscrupulous drug manufacturers and importers (Nwoji, 2006). The Nigerian media - print and electronic - carry features, commentaries and editorials (Udoh, 2005). In terms of news coverage, however, reports are made at the time of arrests, seizure of drugs, closure of illegal drug factories, warehouses, and public destruction of such drugs through burning. From that stage on, little is heard, seen, or known about the process of trial, conviction, or even acquittal (Amani Newswatch 03/12/1999

(www.gannet.com/go/newswatch/99/March/NW0312). This leaves most media audiences in doubt as to the degree of efficiency and effectiveness of the war against drugs, through NAFDAC activities.

\section{Coverage of Hard Drug-related Crimes}

In the late 80 s and early $90 \mathrm{~s}$, Nigeria became a transit route for hard drugs: cocaine, heroine and marijuana/cannabis. This served to dent the country's image, with Nigerians being subjected to the most demeaning and embarrassing searches at international airports. The Nigerian government, in a bid to stem the tide, established the National Drug Law Enforcement Agency (NDLEA). Following the emergence of NDLEA on the drug control scene, spectacularly sensational arrests were made with an equally sensational coverage in the media, so was the public destruction of seized drugs through burning. In the early days of the enforcement of the law, suspects were brought to the law courts in heavily guarded 'Black Maria' in the full glare of television cameras and microphones. Since then, however, both arrests and trial have virtually become shrouded in secrecy.

\section{Advance Fee Fraud/419 and Money Laundering}

Another type of crime which some Nigerian criminals have perfected within and outside the country, and even through the internet, is advance fee fraud, popularly referred to as 419. This high-profile crime is highly celebrated, with virtually all the newspapers and magazines carrying banner headlines on such crimes, while government and private radio stations report them as major news items (Olatunji, 2005, Oladipo, 2006) in the media, particularly at the point of arrest (Adepegba, 2006, Odebode, 2007). Little update is however, provided thereafter about trial, conviction, discharge and/or acquittal, leaving potential ' $419 \mathrm{ers}$ ' and the general public unsure of the level of government's commitment to the war against the crime for which Nigeria has become notorious in recent times. 
Money laundering as a crime has assumed a global dimension. In developing countries, money laundering is a means through which politicians and public officials siphon or stash away, in foreign countries, huge amounts of public funds.

The global fight against the crime now operates at the highest level internationally, particularly since the September 11, 2001 terrorist attack on the Twin Towers of the World Trade Centre in New York, USA. The fight has become necessary because terrorist financing has been linked with money laundering.

I like to observe that many arrests have been made as a result of violation of these Acts, the latest being that one of the Nigeria's state governors (Ugbeje, Olatunji \& Dike, 2004, Olatunji, 2005, Ugbagwu \& Olasanmi, 2007, Owuamanam, 2006). However, unlike the approach to the coverage of crime discussed above, the arrest and trial of the governor in a London court has been given lavish press coverage on Joseph Dariye, former governor of Plateau State, Nigeria (Olatunji, 2005, Onwuamanam, 2006), former President Ibrahim Babangida (Alli, Oladipo \& Falola, 2006), with a rich background insight into the crime.Indeed, it has sparked the investigation of some other governors and public officials (Ige, 2006, Murray, 2006, Onwuamanam, 2006) for possible culpability.

\section{Sectarian, Ethnic and Political Violence}

These forms of violence and the crimes that travail them are not only a common experience, but are also a common feature of media coverage in Nigeria. The bane of the country's multireligious, multi-ethnic, multi-political, multi-cultural and multi-linguistic society is its susceptibility to violence and crimes. Sectarian, ethnic and political violence, resulting in arson, politically-motivated assassinations (Adeyemo, 2007, Rasaq 2006) large-scale destruction of lives and property are often engineered by religious extremists, ethnic militia, political thugs and their social-miscreant recruits.

\section{What the Media Should be Doing “Matters Arising”}

In this section of the paper, we will focus on matters arising from the discussion so far. The inadequacy or inefficiency with which crime and violence are being reported in the media, challenges us to shift our gaze in the direction of the institutions responsible for managing and containing crime and violence.

First and foremost, the media should begin to concern themselves with how to equip the public with information and knowledge on how to protect themselves against gangsters, armed robbery, burglaries, rape, and even white-collar crimes - corruption in government, fraud in the banking industry, advance fee fraud or 419 . They should begin to critically and insightfully examine the sociology of crime - relationship between criminal offence and intolerable social conditions. The media should cease to treat a criminal or violent act as an isolated event that begins at the moment of commission of a crime or perpetration of violence and end at the moment of arrest. The undercurrents of crime and violence and how society deals with criminals must receive significant attention.

\section{The Focus on the Police}


Our focus on how society deals with crime, violence and their perpetrators must shift our attention in the direction of the police as an institution. At the outset, it must be acknowledged that though the police constitute the primary source of crime and violence reports, the police as an institution is inadequately and inefficiently covered (Newswatch 03/12/1999, (www.gannett.com/go/newswatch/99/March/NW0312). The coverage of the police should seek to elicit answers to question such as: Are police officers poorly trained? Are they underpaid, undermotivated, overworked and understaffed? How much confidence does the Nigerian public repose in the police to want to help provide it with useful and timely information on crimes and criminals? Why does the Nigerian public avoid the police as if the police were a leprous institution? What image has the Nigerian police created with its notorious checkpoints and undisguised bribe-taking on the roads, its unprovoked cases of extra-judicial killings and cases of accidental discharge which occur with sickening frequency? The mass media should begin to beam their searchlight on these and similar questions and issues.

\section{Reporting the Court}

Once the police concludes its investigation and a case has been established against the suspect, the court takes over. The court is the apex institution to determine the culpability or otherwise of the accused. However, the process of determining culpability or otherwise of an accused is usually of interest to the public and should be of critical importance to the reporter. Unfortunately, reporters are usually enamoured by the coverage of arrests and convictions because these are action-packed. Covering a criminal act, as it goes through the judicial process, is more arduous and time-consuming.

Thus, Amari in www.gannet.com/go/newswatch/99March/NW0312 has cited Wallace Westfeldt and Tom Wicker, authors of Freedom-funded report titled "Indictment: The New Media and the Criminal Justice System" as identifying the following inadequacies in reporting court process:

Reporters cover trials like horse races; there is a winner and a loser.

Reporters seldom ask, understand or report why juries, lawyers and judges do what they do.

Reporters tend to quote legal documents such as indictments that have more sense of legitimacy to them than denials of the accused.

Because court reporters' sources are often prosecutors and judges, there is a tendency to overreport from that side of the case.

Similarly, Sandman, Rubin \& Sachsman 1976:415 have observed that court reporters often fail to ask pertinent questions such as:

How much do judges differ in the sentences they mete out for the same offence? Which judges are senile or arbitrary, or are consistently overruled on appeal? How long does the average defendant languish in jail before trial and what staffing needs are responsible for the delay? How adequate are the prosecutors and public defenders, the parole officers and other agents of the judicial system? How are juries chosen, and what sorts of people wind up on 
them? Why are so many cases settled by an agreement to plead guilty to a lesser charge (Sandman, Rubin and Sachsman 1976: 415).

Perhaps to the above, we should add: What political, ethnic/tribal and religious undercurrents influence verdicts? Why are interlocutory injunctions so generously granted by some judges and not others, even for the same offence? And even at night?

\section{Reporting the Prison, Remand or Juvenile Homes}

In this part of the paper, we shall take a look at the correctional aspect of the criminal justice system. The prison, remand or juvenile homes are expected to be reformatory (Amari, 1999). Unless they are run and managed accordingly, most inmates who certainly will be rejoining society later are likely to come out more embittered, hardened and less able to fit back in society than they were on conviction. This provides a sound justification for the media to turn their searchlight on these supposedly corrective institutions. Unfortunately, the prison and its allied intuitions are grossly underreported in the media (Amari, 1999). Reporters usually wait until there is either a major prison riot or jailbreak to cover or investigate the situation of the prison and its inmates.

Questions that should agitate the mind of a prison reporter include: how are prisons staffed? Are the staffs adequately trained, equipped and motivated? Are prisons adequately funded? What are prisons cells like? Do inmates have to sleep on bare floor? Are there programmes designed to launch inmates back into productive life after release? How does the prison treat cases of inmates on suspended sentence, or those awaiting trial? What criteria are used for granting certain inmates prerogative of mercy, and not others?

\section{Reporting Crime as Epidemic}

An emerging approach to the coverage of crimes and violence is to report both as a publichealth problem. In this direction, The Berkeley Media Group book, Reporting on Violence: A Handbook for Journalists, opens with a quote from Dr. David Satcher, Director of the U.S. Health Service "If violence is not a public-health problem why are all these people dying from it".www.gannette.com/go/newswatch/99/match/NW03/12"

This approach, which transforms crime and violence coverage to the plane of community coverage, throws up a challenge to the reporter to engage in both mental and psychological re-conditioning. The reporter must critically re-examine the routine, conventional approach to coverage of crime and violence in favour of treating crime and violence stories as he will normally treat stories about an epidemic. In practical terms, this approach demands that the reporter include three classes of information in crime and violence stories: In Anam's words, this includes:

Perspective: In other words, how common is this crime in the community?

Identified Risk Factors: What is the relationship of those involved? Was alcohol (or drug) involved? Do the people involved in the incident have jobs? If a gun was used, who manufactured it? Where was it obtained and how much did it cost? (Parenthesis mine). 
Consequences and Costs: What happened to the families of those involved in this incident? Who pays for their hospitalization? Will the children receive counseling? Will the children be split up, put in foster care?

www.nierman.harvard.ede/reports, observed a group of physicians who, in 1997, met to draw up a list of steps to take to prevent premature deaths in the U.S., that is, deaths occurring before age 65, and discovered, to their surprise, that among the top five were violent injuries, homicide and suicide. To this end, in 1984, the U.S. Surgeon-General declared that "violence was as much a public health issue for today's physicians as smallpox was for the medical community in previous generations".

Below are a few suggestions for reporting crime and violence as a public-health issue or epidemic. The principle of giving a public-health twist to crime and violence reporting can be incorporated into stories, the size of the organisation notwithstanding.

Eliminate short briefs: They offer no context or useful information.

Create a local violence database that lists violent incidents accumulated from a variety of sources, including law enforcement (police reports), criminal justice (coroner reports, restraining orders) and public health (hospital discharge data, emergency room data). Link this to a geographic information system GIS component so that reporters and editors can more easily identity crime trends. Include a story-mapping component in the database so that reporters and editors can see, at a glance, what stories have been published in which categories.

Have a violence reporter who is trained in computer-assisted reporting, one with a science or medical reporting background and familiarity with epidemiological methods.

Organize the team around the violence-prevention reporter who monitors the local, state and national databases, as well as public health research. This reporter presents the information to the team, which decides on how to develop stories, based on data. The police and court reporters continue to do their traditional coverage, augmented by what they can retrieve from the database with the help of the violence reporter.

For every violence incident, include risk factors, such as the type of weapon, relationship or victim to perpetrator, whether alcohol or other drugs were involved, whether the perpetrator and victim have families. Include as much initial information about consequences as possible: what happens to the families? What is the cost of incarceration? Stevens (1998)

www.nierman.harvard.ed/reports. The above underscores the critical significance of reporting crime and violence as community problem or public health issue. Where and when the media, the public and epidemiologists begin to internalise the concept of crime and violence as a community or public-health issue, the spate of their occurrence is bound to suffer decline.

It is heartening to note however, a marked departure from the routine, individual and episodic media coverage of violence and crimes to the group and thematic approach, the just concluded probe of N628m renovation of the speaker's house of the House of Representatives, Mrs. Patricia Etteh's and that of her deputy is a good example of this (Ibrahim, 2007, Ibrahim, \& Oluwasegun, 2007). This welcome shift provides an opportunity for insightful analysis that is facilitative of media audiences' understanding and appreciation 
of the undercurrents of violence and crimes in the Nigerian society with a view to curtaining them.

\section{Conclusion}

This paper has underscored the deep and pervasive sense of insecurity of life and property occasioned by the twin of crime and violence which the paper argued is being covered deficiently in Nigerian mass media. As "matters arising", the paper has turned it searchlight on Nigeria's system of justice, raising a good number of questions that should agitate the minds of crime and violence reporters, as they embark on the sacred responsibility of covering crime and violence in Nigerian mass media.

\section{REFERENCES}

Adepegba,A (2007). "Robbers Shoot One Another While Sharing Loot". The Punch. Tue. Mar. 15 p.6 www.punchontheweb.com

Agbambu, C., Bakoji, S \& Abubakar, U. (2004). "Mobile Policemen Deployed to Plateau“". Daily Independence Wed. May 5.p1 www.dailyindependentng.com.

Azuatalam C. (2007). "Gunmen Kill Seven-month Old Baby in Rivers”. The Nation Fri. Sept. 21 p.5 www.thenationonlineng.com.

Azuatalam, C. O’neil, S \& Okafor , E.(2007). “Aftermath of Military, Cultist Clash:

PortHarcourt Residents Relocate". The Nation. Fri. May 4. p4.

http://www.thenationonlineeng.com

Dike, A. \& osho (2005). "Plateau Assembly Shuns EFCC Over Dariye". New Age. Thur. Dec. 1 p1. www.newageonline.com

Dorfman, L. and Thorson, E. (1998). "Measuring the Effects of Changing the Way Violence is Reported": The Nigerian Foundation of Journalism at Harvard University. Vol. 52, No. 4 Winter.

Efeizomor, V (2004). “Alleged 419: Try Me Now, Ajudua Cries Out”. Daily Independent. Thur, July 8. p.1 www.dailyindependenceng.com

Ericson, R.V., Baranet, P.M., Chan, J.B.L. (1991). Representing Order, Crime Law and Justice in the News Media. Toronto: University of Toronto Press.

Folarin, A.B. (1998). Theories of Mass Media: Ibadan: Stirling. Horden Nig. Ltd. Htt://us.f514.8/13/2004.

Goleman, R. (1999). "Crime and Violence in Prime". A Discurse Analysis of Television News Magazines Use of the Public Health Model of Reporting: Paper presented at ICA Annual Conference held in San Francisco.

Hirkhom, M.J. (1996). "Violent Crime”. Nieman Reports, Vol. 50, No. 3 Pp. 4 - 9. 
Ibrahim, L \& Oluwasegun, V (2007). "N628m Contracts Probe". Committee Indicts Etteh". Thur. Sept. 27, p1. The Nation. http://www.thenationonline.com

Ibrahim, L. (2007), "N628m House Contract: What Etteh'1l Tell Panel”. The Nation. Fri. Sept. 14 p.1 http://www.thenationonline.com.

Ige, I(2006). "EFCC Seizes N7bn assets of INEC Dead Director". Vanguard Wed. Sept. 6 p1 www.vanguardngr.com

Issac. A(2006). "EFCC Men Arresr Ex-governor Audu". The Nation. Thur. Nov 30 p.1 http://www.thenationolineng.com.

Iziguzo, J (2007). "10 Feared Dead in Oyo: Thugs Seize Ibadan by the Throat in Bloody Council Polls". The Nation. Fri. May 25, p1. http://wwwthenationonlineng.comm.

Iziguzo, S (2007), "How We Robbed Redemption Camp". The Nation. Thur. Sept. 20. p.5 http://www.thenationonline.com

Mojeed, M (2007). EFCC to Probe Babagida's Assets in France”. The Punch Tue. Jan. 30 p.5 www.punchontheweb.com.

Nwoji, E. (2006). "NAFDAC Goes Tough on Onitsha Drug Dealers". Daily Champion Thur. June 23. p.32. www.champion-newspapers.com

Nwosu, I. (2002). “The Role of Community in Crime Prevention and Management”. Nigerian Journal of Communications, Vol. 1, No. 1, P. $45-53$.

Oditta, M (2004). "Police Kill 18 Robbery Suspects in Shoot-out". Daily Independence Mon. Sept 13. p.E7 ww.independentng.com.

Ogunmodede, B(2007). "Three Die, 15 Injured as Robbers Attack Bank, Burn Police Station:. The Nation. Sat 4 p.6 http://thenationonlineng.com

Okoli, A. (2007). “ Onitsha: NAFDAC burns N6.5b Fake Drugs”. The Vanguard .Fri. April 6, p.11. www.vanguardngr.com

Olaniyi, (2006). "Militants Kidnap Four Expatriates in Bayelsa”. The Punch Dec. 8 p.13 www.punchontheweb.com.

Olasanmi, K. (2007). "Bail Conditions Keep Ex-governors in Prison". The Nation. Mon. July 30 p.1 http://www.thenationonlineng.com

Onayemi, T. Ogunseye, B. Ogunowa, D. \& Lawal, D (2005). “ Robbers Hit Pentecostal Church" New Age Thur. Aug. 25 p.1 www.newageonline.com

Rasaq, T (2006). "How Funso Williams was Murdered: Riots in Lagos”. The Punch July 28 pp1-2. www.punchontheweb.com 
Sandman, P.M., Rubin D.M. and Sachsman D.B. (1976). Media: An Introductory Analysis of Media of Mass Communications 2nd ed.) Englewood Cliffs, New Jersey: Prentice Hall, Inc.

Severine, W.J. and Tankard, J.W. Jn. (1992). Communication Theories: Origin, Methods and Uses in the Mass Media, New York: Longman.

Stevens, (1998). www.nierman.harvard/edu/reports

Udo.ma, D. (2006). "Day Akunyili Took Drug War to Eket". Daily Champion. Wed June 28 p.12 www.champion-newspapers.com

Udoh, F(2005). “NAFDAC Seizes N25m Fake TopGel”. Daily Champion wed. Aug. www.champion-newspapers.com

Ugbagwu, E \& Olasanmi, K. (2007). "Yar' Adua Cant Help Troubled Ex-governors: Kalu Meets Prsident, Nnamani gets Bail, Turaki Blame fate on Lamid". The Nation. Fri. Aug. 3 p1. http://www.thenationonlineng.com

Ugbagwu, E (2007). "N1.7billion Cash Seized from Alamieyeseigha: Ex-Bayelsa Governor Loses Chelsea Hotel, Other Properties". The Nation. July 31 p1.

http://www.thenationonlineng.com

Williams R \& Oyekunle, J. (2006). “Confessions of a Drug Courier”. Sunday Punch, July 2 p.5. www.punchontheweb.com.

www.gannett.com/gonewatch/99/March/NW03/12.

www.presscouncil.org.au(2000) 